\title{
地球規模の灌溉用水要求量とその水源に対する 気候変化の影響 IMPACTS OF CLIMATE CHANGE ON GLOBAL IRRIGATION WATER REQUIREMENT AND ITS SOURCES
}

\author{
眞㠃良光 ${ }^{1} \cdot$ 花崎直太 ${ }^{2} \cdot$ 高橋潔 $^{3} \cdot$ 肱岡靖明 4 \\ Yoshimitsu MASAKI, Naota HANASAKI, Kiyoshi TAKAHASHI and Yasuaki HIJIOKA

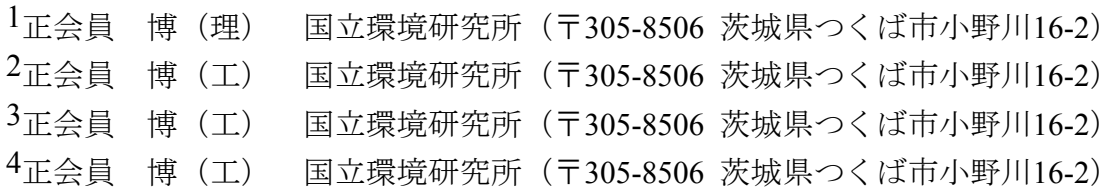

We have evaluated evapotranspiration from different types of cropland and its water sources under future climate conditions when the current cultivation and irrigation practices will be kept in the future. A future increase in evapotranspiration from irrigated croplands will be larger than that from rain-fed croplands. To compensate increasing water loss from irrigated croplands through evapotranspiration, a larger amount of water will be supplied from non-river water sources than today: cultivation of the second crops in a double-cropping system in India is a typical example. Additional adaptation measures will be necessary to prevent future water shortage where the capacity of currently existing reservoirs or groundwater will be insufficient for future irrigation requirement.

Key Words : Irrigation water, climatic change, cropland type, water resources, crop evapotranspiration

\section{1. はじめに}

水は人間活動に不可欠な資源であり，将来にわたって 必要な水資源量を確保できるかは，持続可能な地球・社 会システムを構筑する上で主要な課題の一つである．現 在，人為活動に伴う取水量のうち，灌溉用水が全体の約 7 割を占めており, 最も主要な取水用途になっている11 灌泊は，作物生育の水ストレスを防ぎ，乾燥地での栽 培や多毛作を可能にすることで，食糧生産量の増加に貢 献してきた. 少なくとも今後数十年間は世界人口の増加 が見込まれ ${ }^{2}$, 農地拡大や単収増による食糧生産量の増 加が求められており, 同時に灌溉の需要が増えることも 予測される. 加えて, 温暖化による農地からの蒸発散が 促進されることによる灌洦水量の増加も予測されている これら灌泊水量が増加する要因がある中，無秩序な灌泊 取水は，河川流域の水不足を誘発する可能性がある，気 候変動影響予測のためのモデル間相互比較プロジェクト Inter-Sectoral Impact Model Intercomparison Project（ISIMIP) ${ }^{3)}$ の初期成果からも，河川流域における灌泊取水
の問題が指摘されている4).

灌㿡水量が増大する中，持続可能な水利用の実現は大 きな社会問題である。これまでの水資源評価に関する研 究では，河川流域毎に河川流量を評価し，灌激等水使用 量との需給バランスを議論してきた. しかし, 多毛作栽 培や灌溉栽培が，水資源をどの程度圧迫し，これらの栽 培様式を変更することで水不足を回避できるかについて は，検討するための基礎的情報が不足している．具体的 には，地域毎に異なる栽培様式が，将来，どの程度の灌 溉水量を必要とし，それをどの水源に依存するのかを評 価した研究事例は少ない.

そこで本研究では，最新の将来気候シナリオに従って， 将来, 現存の多毛作栽培・灌潛農地を維持する場合, 作 物生育に必要となる水について, (1)水源（降水, 河川, それ以外) 別，および(2)農地利用（二毛作・一毛作およ び灌泊の有無）別に評価し，それぞれの将来変化を調べ た. 農地に供給された灌溉水は，蒸発散や流出により失 われる. 後者は, 灌溉により土壌水分が定常的に高めに 維持されるため, 降雨時以外はほぼ定常であるのに対し， 前者は，気候条件により大きく左右される，そこで本研 
究では, 水文モデルによる計算の利点を活かして, 灌泊 により農地に供給されてから蒸発散として失われるまで の水の流れを追跡し，それぞれの水量を記録することで， 各地域の農地利用と将来の灌溉水源依存性との関係を調 べた.これにより, 温暖化に伴う気象条件の変化に対す る水源別・農地利用別蒸発散量の応答と, その大きさの 地理的分布を明らかにすることを目的とする.

\section{2. 手法}

将来気候として, ISI-MIPが作成し, 配布・提供して いる $5 つ$ つCM気象データセット (GFDL-ESM2M, HadGEM2-ES, IPSL-CM5A-LR, MIROC-ESM-CHEM, NorESM1-M）を用いた。 空間分解能は $0.5^{\circ} \times 0.5^{\circ}$ であり， 全球陸域について現在（1951～2005年）および将来

（2006２099年）をカバーしている. 将来の気候は， 4 種類の代表的濃度パス ${ }^{5}$ （RCP2.6，4.5，6.0，8.5）に基 づく. 湿度以外の全気象要素入力值にバイアス補正が適

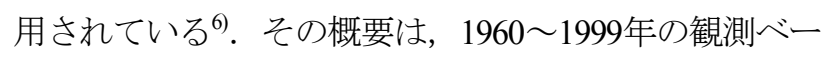
スのWATCH気象データ7) と各GCMのデータから, 気象 要素日別值の累積度数分布をそれぞれ求め, 前者の分布 に合うように後者を変換する補正法である．変換関数は 月ごとに決めるものの，月初・月末における気温等の不 連続性を避けるため, 変換関数のパラメータを補間して 適用する.

水文モデルはH08)を使用し，上記日別值の気象デー 夕を入力し，水文過程（積分計算の時間間隔1日）の計 算をした. ダム運用は, 将来の運用に関する不定性が大 きいため, 本研究では現在・将来ともに扱わないことと する.

H08では，1つの陸域セルに対して，異なる水管理環

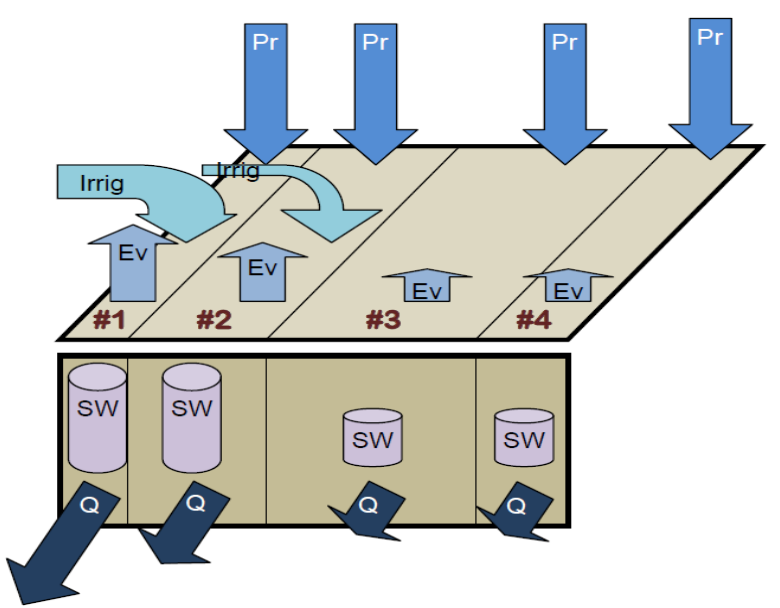

図-1 H08における再分割の概念図．陸域セルを，4種類の農

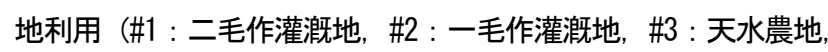
\#4：その他）に各面積割合に応じて分割する. モザイク毎に独 立した灌袙様式を設定することで，同一地点であっても，農地 利用ごとに異なる蒸発散量，土壤水分量を持つ.
境下での水文過程計算ができるように，再分割する機能 が設けられている（図-1）。本研究では，1つの陸域セ ルを 4 つの農地利用（二毛作灌泊地，一毛作灌泊地，天 水農地，その他）に分割し，それぞれをモザイク\#1，\#2， \#3，\#4と呼ぶ. 灌泊農地面積についてはSiebert" ${ }^{9}$ を用いた

（各農地利用の分布を図-2に示す）。栽培作物は Monfreda ${ }^{10)}$ のデータに基づき, 主要19作物種に再編集し た上で，二毛作灌溉地では，そのセルにおける最大およ び第 2 位の作付面積作物（以降, 主作物, 副作物と称 す）を，一毛作灌溉地および天水農地では，最大作付面 積作物を栽培することとする。灌洦条件（灌溉期間や灌 溉面積の増減，維持すべき土䁃水分量など）・栽培条件

（栽培作物種や作付面積の増减など）の将来変化予測は 難しいため, 現状（2000年）の值に固定した．栽培暦は 1971〜2000年のWATCH気象データに基づき, 最大収量 の得られる平均植付日を求め, これを将来にも適用した. ただし，作物の生育・登熟は積算気温に基づいて計算

(作物種ごとに決められたSWIM ${ }^{11)}$ の生育パラメータを 使用）するため，栽培期間は将来の気候条件によって変 わる.

灌溉農地では，栽培期間およびその前30日間，作物が 水ストレスを感じない土壤水分量（戋場容水量の $75 \%$, 水田は同100\%）を維持できるように，灌溉用水を供給 し続けるものとする. 本研究では, 農地に供給される水 源として, 降水, 河川水および非河川水を考える. 水源 から農地を経由して蒸発散として失われるまでの水量を, 水源別・農地利用別に記録寸る．水源別解析の妥当性は,

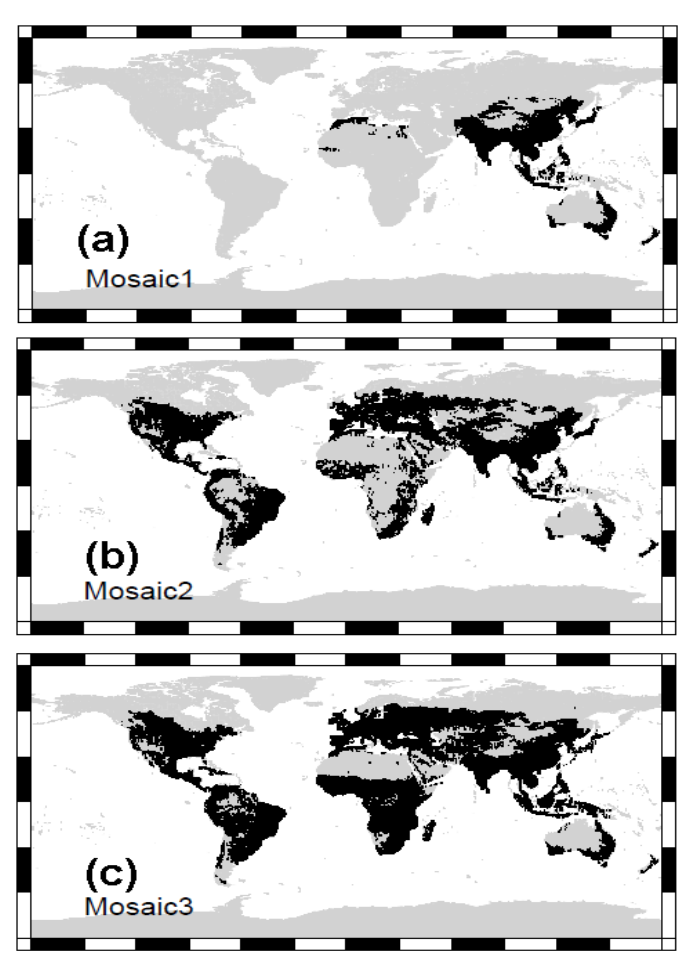

図-2 本解析で使用した農地利用とその分布（黒色部分） （a）二毛作灌溉地，（b)一毛作灌溉地，（c）天水農地. 
観測值が存在しないため，同種水文モデル解析結果との

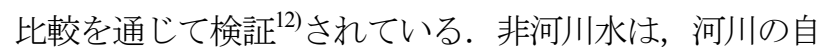
然流量以外から得るすべての水源（貯水池や地下水，ダ ム操作による河川流量割増分も含む）を包含したものを 想定しており，上記灌溉条件を河川取水のみで維持でき ない場合, その不足分を非河川水源から取水するものと する. この仮定により，河川・非河川起源を合わせた灌 溉水量は, 水ストレスのない理想条件下での灌泊栽培に おいて必要になる水量を与えることになる.

灌溉以外にも, 工業用水, 家庭用水を, 河川から取水 した。これらの水量に関しては, 国別統計データ AQUASTAT ${ }^{13)}$ から, GPWv3 ${ }^{14)}$ の人口密度分布に応じて 各セルに水使用量を配分して，セルごとのデータを用意 した．将来の不確定性が大きいため，2000年の值で固定 した.

\section{3. 結果と考察}

\section{（1）水源別 - 農地利用別の作物栽培期間中の蒸発散量変} 化

まず，作物栽培期間中の蒸発散量について，農地利用 ごとに面積割合に応じた重み付けをして全球平均をとり, 全体的傾向を把握寸る．図-3は，現在（1971～2000年） および将来（2070～2099年）の作物栽培期間中の蒸発散 量であり，また，現在值に対する将来の変化率を表-1に 示す.

灌襛地では，現在気候下において蒸発散を通じて1 回の作付あたり $400 \mathrm{~mm}$ 程度を消費しており，その水源を 降水と灌溉水でほぼ半々に分けあっている. 二毛作灌溉 地での副作物栽培期間中の全蒸発散量は, 他の灌泊地の 結果とほぼ同じであるのに対し，降水への依存度が小さ い. これは，主作物に比べて天水環境が厳しい条件（栽 培季節など）下で栽培されているものの，灌溉により作 物を水ストレスから防いでいる状況が示唆される. 天水 農地は，灌泊農地よりも泠涼な高緯度地域にまで広く分 布していることに加え，土壌水分量が低いために作物の 蒸発散量が抑制される効果もあり，栽培期間を通じた蒸 発散量は, 灌雄農地の結果に比べて小さい.

将来, いずれの灌溉農地においても全蒸発散量の増加 が認められ，温暖化が進む気候シナリオ（RCP8.5）ほど 大きく増加する. 東南〜南アジアにかけて多く分布する 二毛作灌溉地では, 降水・河川水起源の蒸発散量も増加 しているものの，非河川灌溉水の増加が著しい，温暖な 地域を中心に全球に広がる一毛作灌溉地では，降水起源 がほぼ不変ないし微减するのに対し, 灌溉起源の割合が 増加し, 特に非河川水起源の増加が顕著である. 乾燥地 や寒冷地以外の全球に広がる天水農地では, 将来も蒸発

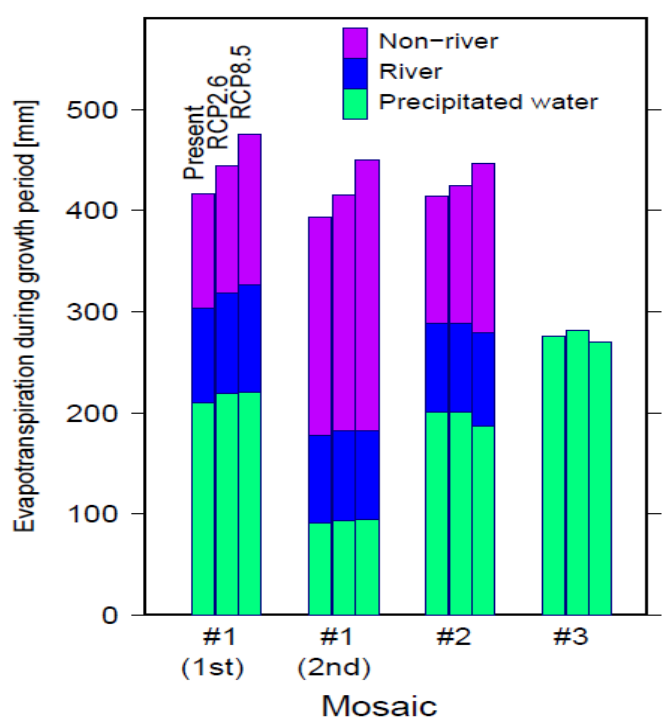

図-3 水源別 - 農地利用別の栽培期間中の蒸発散量 $[\mathrm{mm}$. 対象 農地利用について全球を平均した値であり，5つのGCM平均を とつた．二毛作灌溉地井1については，主作物 $\left(1^{\mathrm{st}}\right)$ と副作物 ${ }^{\left(2^{\mathrm{nd}}\right)}$ に細分した. 各モザイクについて, 左から順に現在,

RCP2. 6, RCP8.5の結果を示し，水源別に色分けした．なお，\#3 は天水農地であるため, 降水起源のみが対象となる.

表-1 水源別 - 農地利用別の栽培期間中における蒸発散量の,

現在（1971 2000年）に対する将来（2070 2099年）の変化率 [\%]。毛作灌溉地\#1については，主作物 $\left(1^{\text {st }}\right)$ と副作物 (2n) に細分した.

(a) RCP2. 6

\begin{tabular}{lrrrr}
\hline 水源 \モザイク & $\# 1\left(1^{\mathrm{st}}\right)$ & $\# 1\left(2^{\mathrm{nd}}\right)$ & \multicolumn{1}{c}{$\# 2$} & $\# 3$ \\
\hline \hline 降水起源 & +4.4 & +3.1 & 0.0 & +2.3 \\
\hline 河川水起源 & +6.0 & +1.3 & +0.2 & - \\
\hline 非河川水起源 & +12.1 & +8.6 & +8.2 & - \\
\hline (全水源) 蒸発散 & +6.9 & +5.7 & +2.5 & +2.3 \\
\hline & (b) RCP8. 5 & & & \\
\hline
\end{tabular}

\begin{tabular}{lrrrr}
\hline 水源 \モザイク & $\# 1\left(1^{\mathrm{st}}\right)$ & $\# 1\left(2^{\mathrm{nd}}\right)$ & \multicolumn{1}{c}{$\# 2$} & \multicolumn{1}{c}{$\# 3$} \\
\hline \hline 降水起源 & +4.9 & +3.6 & -6.7 & -2.0 \\
\hline 河川水起源 & +14.3 & +1.4 & +4.7 & - \\
\hline 非河川水起源 & +31.9 & +24.2 & +33.1 & - \\
\hline (全水源) 蒸発散 & +14.3 & +14.4 & +7.9 & -2.0 \\
\hline
\end{tabular}

散量はあまり変わらない。

灌溍農地では栽培期間中の土袞水分量が高く維持され ているため, 常に可能蒸発散量に近い蒸発散が実現され ていると考えられ, 気温上昇が蒸発散量の増加につな がっている. これに対し, 天水農地では, 気温が上昇し ても降水量が増えない限り土壌水分量による蒸発散の抑 制効果が働き, 蒸発散量があまり増えなかったものと考 えられる.この理由の裹付けとして, 天水農地における 栽培期間中の全球平均蒸発散量が将来もほぼ変わらない

(現在 $275.3 \mathrm{~mm} ， \mathrm{RCP} 8.5$ における将来 $269.7 \mathrm{~mm}$ : 図-3) 
のに対し, 同じ方法で求めた可能蒸発散量は増加（それ ぞれ509.7mm，587.1mm：図未掲載）していることが挙 げられる，灌溉水源として，河川水より非河川水への依 存度が大きくなっているが，河川流量はその地域あるい は上流域の降水量に支配されることを考えると，降水量 が増加しない限りは河川流量の増加も見込めず, 必要な 灌溉水を河川以外に求めざるを得ないものと考えられる.

\section{（2）作物栽培期間中の蒸発散量の将来変化に見られる地 理的分布とその特徵}

気候条件によって蒸発散量が変わるとともに，降水量 や河川流量などの水資源量も異なるため, 地域によって 水源別の灌泊水供給依存度も異なる. 前節では全球での 傾向を捉えたので，本節では各地域の特性を解析する.

作物栽培期間中の蒸発散量について, 水源別の将来変 化量を図-4に示す，以下ではRCP8.5を例に記述するが， 温暖化が進むシナリオほど変化量が大きくなる傾向があ り，増減の傾向や地理的分布はRCPによらず同様の傾向 を示す。

二毛作灌溉地では，全球での傾向を反映して，降水・ 河川起源の蒸発散量がやや増加し, 副作物に比べて主作 物の蒸発散増加量の方がやや大きい. 非河川水起源の蒸
発散量は大きく増加し, 特に副作物栽培期間中のインド や地中海沿岸では $100 \mathrm{~mm}$ 程度以上の増加を示す。

一毛作灌溉農地では, 降水起源の蒸発散量に二つの傾 向が見られる. 将来降水量が減少するヨーロッパ中部〜 地中海周辺やアメリカ西岸では, 降水・河川起源の蒸発 散量も減少する。 それ以外の地域では，降水・河川起源 の蒸発散量が微増する。、ずれの地域も, 非河川灌筂水 起源の蒸発散量は増加し, 中南米やアフリカの一部では 100mm近い増加を示す地域がある.

天水農地でも, 将来の降水量変化傾向と似た蒸発散量 の変化傾向を示し, ヨーロッパ中部〜地中海沿岸やアメ リカ穀倉地帯で咸少するが，アフリカ赤道地域，東～南 アジアでは増加傾向にある. これは, 気温上昇による蒸 発散の活性化と, 降水減少により土壤水分の減少を介し た蒸発散の抑制化との, 両効果の大小によって地域的差 異が生じるものと考えられる.

つぎに特徽的な将来変化を示す 2 地域を詳しく解析寸 る.インド南部 $\left(70^{\circ} \mathrm{E} \sim 90^{\circ} \mathrm{E}, 10^{\circ} \mathrm{N} \sim 20^{\circ} \mathrm{N}\right)$ とヨー ロッパ中部〜地中海沿岸 $\left(0^{\circ} \sim 20^{\circ} \mathrm{E}, 40^{\circ} \mathrm{N} \sim 50^{\circ} \mathrm{N}\right)$ に 矩形領域を設定し, 領域内での蒸発散量の平均をとる以 外は，前節と同様の解析をする. その結果（図-5) を， 全球での結果（図-3）と比較する.

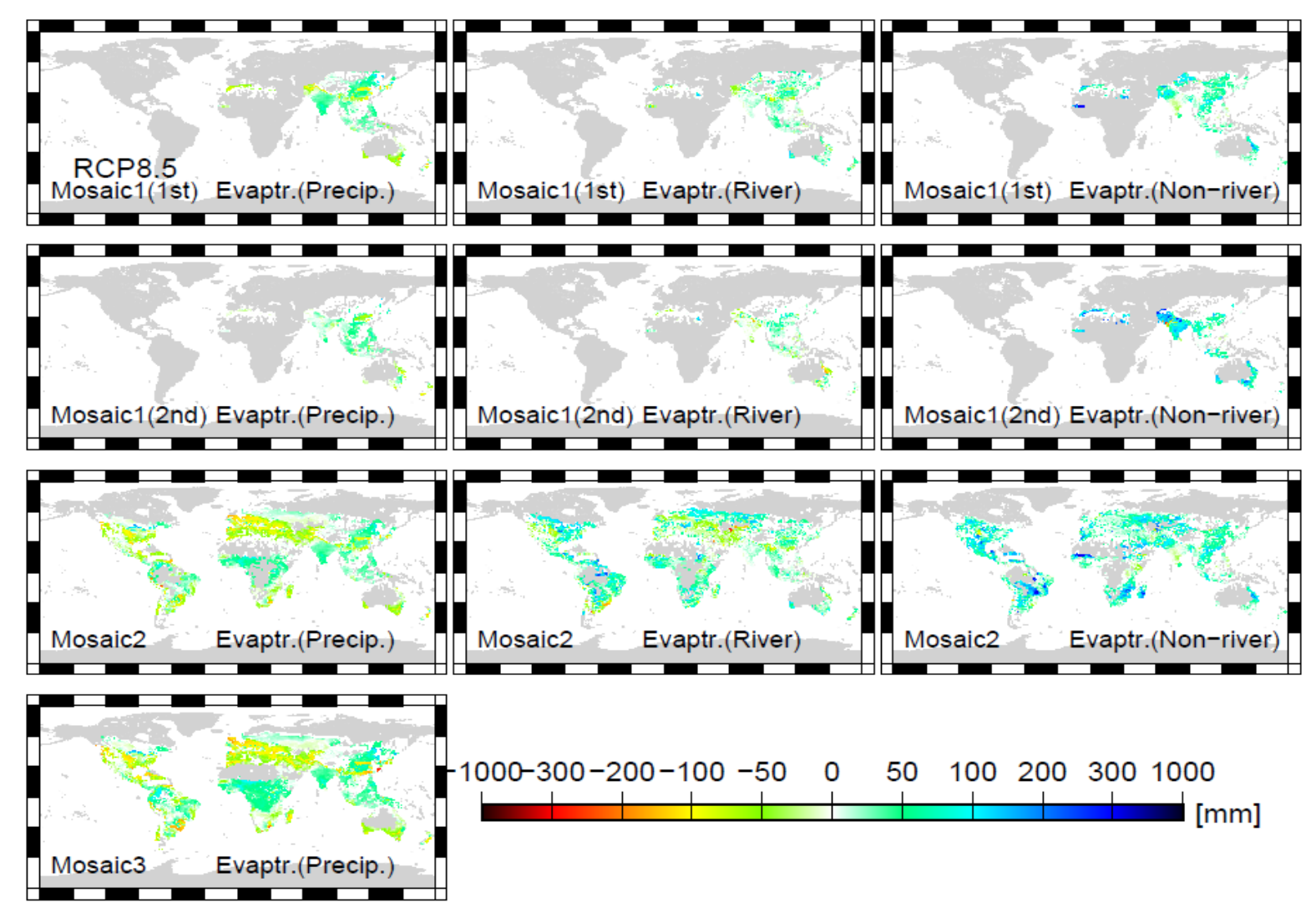

図-4 水源別・農地利用別の栽培期間中における蒸発散量の将来変化量 $[\mathrm{mm}] （ 1971 ２ 000$ 年に対する2070～2099年の変化量）. 気 候シナリオはRCP8.5を使用し，5つのGCMの平均をとった. 各パネルは上段より，二毛作灌篦地の主作物，同副作物，一毛作灌溉地， 天水農地であり, 水源別に, （左）降水起源, （中）河川水起源, （右）非河川水起源を示す. 
(a) India

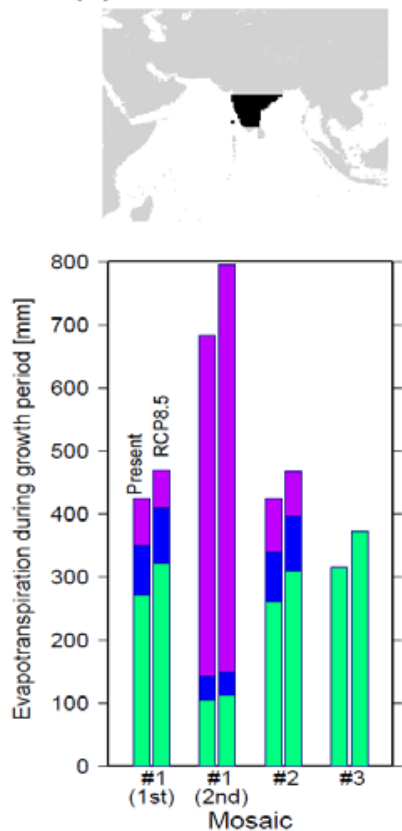

(b) Europe
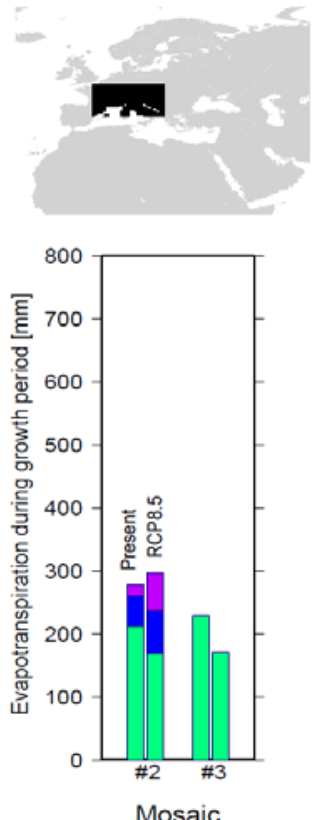

図-5 特徵的な 2 地域（(a)インド南部，(b) ヨーロッパ中部〜 地中海沿岸）における水源別・農地利用別の栽培期間中の蒸発 散量 $[\mathrm{mm}]$. 図-2に示した各農地利用について，対象領域（挿入 地図に黒で塗りつぶした領域）内の平均をとった．各モザイク について, 現在とRCP8.5の結果を示したものであり, 水源に関 する凡例は図-3に同じ.

インド南部の場合，二毛作灌溉地の主作物の全蒸発散 量は，全球平均と同程度の400～500 mm 程度であるが, 降水起源の割合が大きい. 主作物の栽培期間が，主にモ ンスーンの雨期にあたるためである。一方，副作物の全 蒸発散量はその倍近い700mm程度におよぶものの, 降水 起源は $100 \mathrm{~mm}$ 程度にとどまり，残り大部分は灌溉水に よって賄われている。栽培期間がモンスーンの雨期から 外れているためである. 灌潛水の内訳を見ても, 河川水 起源は40mm程度と少なく, 非河川水に大きく依存して いることが分かる. 将来（RCP8.5）の蒸発散量も，二毛 作灌溉地の副作物栽培期間での増加が顕著であり，その 増加分のほとんどを非河川水に求めなければならない.

ヨーロッパ中部〜地中海沿岸の一毛作灌溉地では，全 蒸発散量が300mm程度と小さいものの，その 6〜 7 割近 くが降水でまかなわれている，将来，蒸発散量は増加す るものの, 降水量が減少するため, 降水への依存度が下 がる. その不足分を灌溉水で補っている.

\section{4. 議論}

（1）栽培期間と蒸発散量とのトレードオフ

気温の上昇は蒸発散を促進させるため，灌溉取水量が 増加する. 一方, 作物生育速度は（生育に適正な温度レ ンジ内であれば）気温が高くなると速くなるため, 温暖

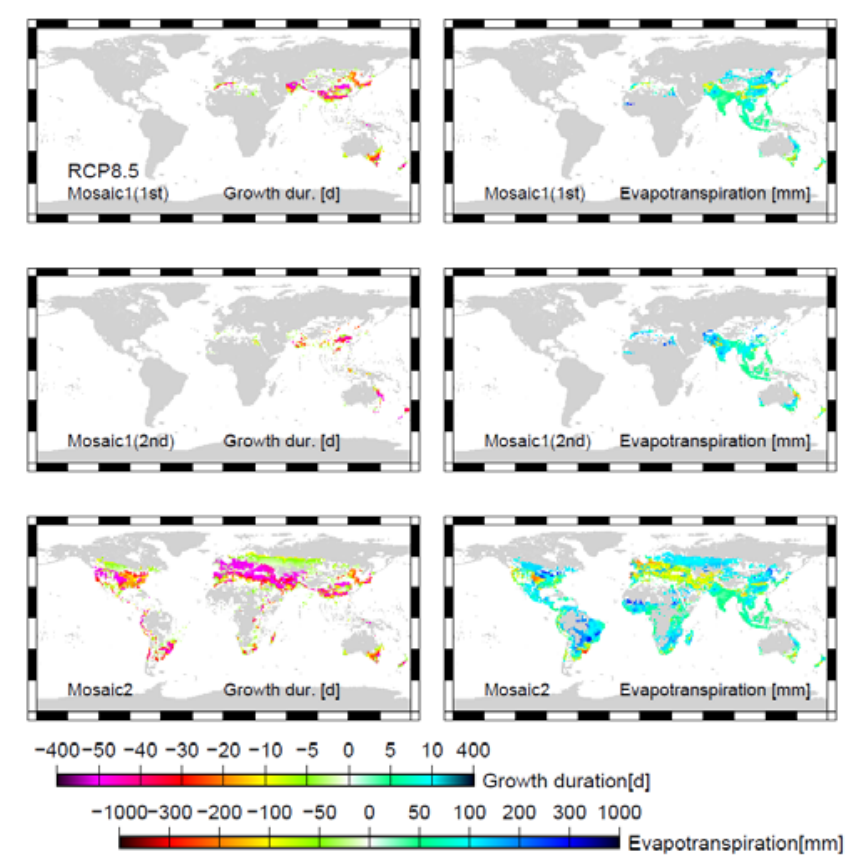

図-6 現在に対する将来の（左）作物栽培日数の変化 $[\mathrm{d}]$, およ び (右) 栽培期間中の蒸発散量の変化量 $[\mathrm{mm}]$. 気候シナリオは RCP8.5を使用し，5つのGCMの平均をとった. 上から順に，二毛 作灌溉地の主作物, 同副作物, 一毛作灌溉地に対する結果.

化により栽培期間が短くなり，灌溉期間が短縮され，灌 泊取水量が減少寸る。では，この二者のどちらの効果が 勝るのだろうか.

将来気候下における灌泊農地の栽培期間の変化と, 栽 培期間中の全蒸発散量（各水源の総和）を図-6に示寸. 地理的条件や気候シナリオによって異なるものの，概し て，10日程度の栽培期間の短縮があったとしても，栽培 期間中の蒸発散量は増加する地域が多い。しかし，地中 海沿岸や米国南西部など，数十日規模での栽培期間の短 縮が見られる地域では，それに応じた蒸発散量減少の効 果の方が勝る. 全球で平均すれば，前者の効果が卓越す るため, 図-3のように蒸発散量が増加すると解される.

なお，本モデルでは，高 $\mathrm{CO}_{2}$ 環境下における植物の生 理学的応答（気孔開度の減少による蒸発散の抑制）を 扱っていない．葉面積増大による蒸発散増加との相殺効 果もあり, 植物種によって全蒸発散量一の影響は大きく 異なる ${ }^{15}$. 現在, 高 $\mathrm{CO}_{2}$ 環境下での栽培実験等を通して

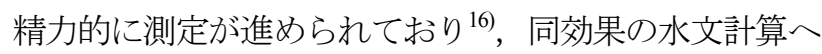
の取り込みは，今後の課題とする.

\section{5. 結論}

現状の栽培環境を維持するとき，二毛作・一毛作の違 いや灌溉の有無と, 将来に必要となる灌溉の取水源との 
関連性を調査するため，水源から農地を経て蒸発散に至 る過程を水文モデルで追跡することで，将来気候下での 作物栽培期間中の蒸発散量を水源別・農地利用別に評価 した. 全球平均での蒸発散量は, 天水農地より灌溉農地 で大きく増加する．このうち，降水や河川からの灌洦水 量は, 現在と同程度ないし微増にとどまるため, 不足分 をこれら以外の水源に頼る必要があり, その水量は現在 より増加すると予測される。灌溉により乾燥地や乾季で の作物栽培が可能になった地域の中には, 将来の降水量 が減少するなど，現在より厳しい栽培環境を強いられる と予測される地域も多く，より多くの非河川灌泊水を供 給する必要が生じる.インドの二毛作灌溉地（特に副作 物) などでは, 非河川灌洦水の水量の大幅な増加が予測 され，もし地下水や既存の貯水池等で賄えない場合は, 新たな貯水池建設等の代替取水源の確保や, 多毛作栽 培・灌溉様式の見直し等の対策が必要となる可能性があ る.

本研究では，将来の気候条件による影響に焦点を合わ せたため, 貯水池を考慮しなかったり, 河川の自然流量 のみを考えたりするなど, 解析条件の簡略化を図った.

より現実的な条件設定の上で解析することが今後の課題 である. また，気候変動に対する適応策として，貯水池 等の代替取水源の確保に向けた検討 ${ }^{17)}$ が既に始まって

いる，農業は，水資源や食糧生産を含む社会システムの 持続可能性を左右する社会の主要産業であり，今後も継 続して研究に取り組むことが重要である.

謝辞 : 本研究は, 環境省環境研究総合推進費(S-10)によ り実施された. 入力気象データとして，ISI-MIPにより 作成・配布されたものを使用した。

\section{参考文献}

1) Wada, Y., Wisser, D., Eisner, S., Flörke, M., Gerten, D., Haddeland, I., Hanasaki, N., Masaki, Y., Portmann, F. T., Stacke, T., Tessler, Z. and Schewe, J.: Multimodel projections and uncertainties of irrigation water demand under climate change, Geophys. Res. Lett., doi: 10.1002/grl.50686 (accepted).

2) United Nations: World population prospects, The 2012 Revision, Highlights and advance tables, Working Paper No. ESA/P/WP.228, 2013.

3) The Intersectoral Impact Model Intercomparison Project (ISI-MIP): Project design and simulation protocol, Version 1.3, 2012.

4) Haddeland, I., Heinke, J., Biemans, H., Eisner, S., Flörke, M., Hanasaki, N., Konzmann, M., Ludwig, F., Masaki, Y., Schewe, J., Stacke, T., Tessler, Z. D., Wada, Y. and Wisser, D.: Global water resources affected by human interventions and climate change, Proc. Nat. Acad. Sci. U.S.A., (accepted)

5) Moss, R.H., Edmonds, J.A., Hibbard, K.A., Manning, M.R., Rose, S.K., van Vuuren, D.P., Carter, T.R., Emori, S., Kainuma, M., Kram, T., Meehl, G.A., Mitchell, J.F.B., Nakicenovic, N., Riahi, K., Smith,
S.J., Stouffer, R.J., Thomson, A.M., Weyant, J.P. and Wilbanks, T.J.: The next generation of scenarios for climate change research and assessment, Nature, Vol. 463, pp. 747-756, 2010.

6) Hempel, S., Frieler, K., Warszawski, L., Schewe, J. and Piontek, F.: A trend-preserving bias correction - the ISI-MIP approach, Earth Syst. Dynam. Discuss., Vol. 4, pp. 49-92, 2013.

7) Weedon, G.P., Gomes, S., Viterbo, P., Shuttleworth, W.J., Blyth, E., Österle, H., Adam, J.C., Bellouin, N., Boucher, O. and Best, M.: Creation of the WATCH forcing data and its use to assess global and regional reference crop evaporation over land during the twentieth century, J. Hydrometeorol., Vol.12, pp.823-848, 2011.

8) Hanasaki, N., Kanae, S., Oki, T., Masuda, K., Motoya, K., Shirakawa, N., Shen, Y. and Tanaka, K.: An integrated model for the assessment of global water resources - Part 1: Model description and input meteorological forcing, Hydrol. Earth Syst. Sci., Vol.12, pp.1007-1025, 2008.

9) Siebert, S., Döll, P., Hoogeveen, J., Faures, J.-M., Frenken, K. and Feick, S.: Development and validation of the global map of irrigation areas, Hydrol. Earth Syst. Sci., Vol.9, pp. 535-547, 2005.

10) Monfreda, C, Ramankutty, N. and Foley, J.A.: Farming the planet: 2. Geographic distribution of crop areas, yields, physiological types, and net primary production in the year 2000, Glob. Biogeochem. Cycles, Vol. 22, GB1022, doi:10.1029/2007GB002947, 2008.

11) Krysanova, V., Wechsung, F., Arnold, J, Srinivasan, R. and Williams, J.: SWIM (Soil and Water Integrated Model) user manual (version SWIM-8), 2000.

12) Hanasaki, N., Inuzuka, T., Kanae, S. and Oki, T.: An estimation of global virtual water flow and sources of water withdrawal for major crops and livestock products using a global hydrological model, $J$. Hydrol., Vol. 384, pp. 232-244, 2010.

13) Food and Agriculture Organization (FAO), http://www.fao.org/nr/water/aquastat/main/index.stm, 2013.

14) Center for International Earth Science Information Network (CIESIN) and Centro Internacional de Agricultura Tropical (CIAT): Gridded Population of the World, Version 3, http://sedac.ciesin.columbia.edu/gpw/index.jsp, 2005.

15) Saxe, H., Ellsworth, D.S. and Heath, J.: Tree and forest functioning in an enriched $\mathrm{CO}_{2}$ atmosphere (Tansley Review No. 98), New Phytol, Vol. 139, pp. 395-436, 1998.

16) Shimono, H., Nakamura, H., Hasegawa, T. and Okada, M.: Lower responsiveness of canopy evapotranspiration rate than of leaf stomatal conductance to open-air $\mathrm{CO}_{2}$ elevation in rice, Global Change Biol., Vol. 19, pp.2444-2453, doi:10.1111/gcb.12214, 2013.

17) Hanasaki, N., Masaki, Y. and Yamamoto, T.: Adaptation measures for the impact of climate change on global water resources - Option 2: Adding storage capacity, Impacts World 2013, International Conference on Climate Change Effects, pp.433-437, 2013.

(2013. 9. 30受付) 